\title{
Economic Growth, Human Development and Inequality
}

\section{Imelda Ortiz Medina ${ }^{1}$; Marlen Hernandez Ortiz ${ }^{2}$; Jorge Martinez Perez ${ }^{3}$}

Dr in Government and Public Administration from the Complutense University of Madrid, research professor at the Autonomous University of Zacatecas, Mexico ${ }^{1}$; Dr in Materials Sciences from the Autonomous University of Sonora, research professor at the Autonomous University of Zacatecas, Mexico ${ }^{2}$; Dr in Sciences of Religions from the Complutense University of Madrid, research professor at the Autonomous University of Zacatecas, ${ }^{3}$ imeldaortizmedina@uaz.edu.mx¹,mar_h2o@hotmail.com²,jorgemartez@hotmail.com³

\section{DOI:10.26821/IJSRC.9.2.2021.9208}

\begin{abstract}
This paper shows the relationship between variables; economic growth, human development and inequality, based on the principle that increased production does not automatically generate an increase in welfare by itself. Its distribution is necessary, so human development, rather than depending on income, is a function of its distribution. For this reason, governments should place greater emphasis on the redistributive mechanisms of wealth. For the study, three groups of countries were chosen and the simple linear regression between $H D I$ and real GDP and between the HDI and the Gini coefficient was calculated, managing to corroborate the hypothesis.
\end{abstract}

Keywords: Welfare, Real GDP, HDI, Gini coefficient, , Fiscal policy

\section{INTRODUCTION}

Today we ask ourselves, what is the objective of the economy, what do we intend when we seek greater economic growth, the answers can be diverse, and all be valid at the same time. However, for us, the economy must have as a fundamental purpose, which is to raise the levels of welfare and human development; ensure that each human being has a dignified life, without deficiencies or limitations and full of opportunities. Economic history shows us the heterogeneity of development Imelda Ortiz Medina; Marlen Hernandez Ortiz; Jorge Martinez Perez, Volume 9 Issue 2, pp 53-60 in which countries and regions operate, it also shows th that the market inherently accentuates marginalization and exclusion. It is then, that we ask ourselves, how to achieve economic growth that accrues welfare.

The answer is not easy, it is not unique and there are many theories, but if there is a certain level of consensus, it is that the mechanisms for growth must first be sought, once this is achieved, the government must implement the instruments for collecting the income and subsequently distribute it. In this article, a quantitative analysis was carried out that shows the relationship of the variables indicated at the beginning, in order to demonstrate that the increase in income does not spontaneously generate welfare, so its distribution is essential to be able to raise the level of human development.

In the first part, the theoretical development on economic growth, human development and inequality is exposed, then there is the discussion on the relationship between these three variables, later the materials, methods and results obtained are described and finally there are the conclusions.

\section{THEORETICAL FRAMEWORK 2.1. Economic growth}

Until the end of the 19th century, it was believed that the economy showed harmonious growth since an invisible hand guided market forces (supply and demand) towards their natural equilibrium. 
Volume 9 Issue 2 February 2021

However, a great crisis - the largest in contemporary economic history, which occurred in the 20th century; the famous crash of 29 (October 1929) - shows the fallacy of market equilibrium. It is then that economists of that time, concerned about events, look for explanations: contributions such as John Maynard Keynes (English Economist 1883-1946) become relevant.

The Great Depression and the contributions of economists of that time, reveal, fundamentally, three important aspects: one is that; the market is not harmonious, supply and demand do not reach equilibrium naturally, two; economic phenomena require a vision of greater magnitude, it is not longer enough to analyze these processes only from the perspective of economic units (companies and families), it is also necessary to study their impacts on all national economic events, so the macroeconomy it enters the scene as one of the major areas of modern economic science. And three; When the ineffectiveness of the free market is revealed, the intervention of a force majeure becomes evident that manages to regulate its basic forces, evidencing the direct participation of the State in the economy: the market by itself is inefficient, particularly if wealth distribution is all about.

Macroeconomics studies the large aggregates such as Production, Employment, Inflation, Exports, etc. Being the main macroeconomic aggregate: "The production of a country" this is the main and most important indicator of economic growth, its behavior manifests itself, the evolution of other variables such as investment, interest rate, exchange rate, among others. .

In the post-Keynesian and neo-Keynesian approaches, countries have unstable economies due to imbalances in effective demand and excess supply, which can be corrected with the active participation of the State; increasing public spending and regulating the power of large companies and the financial sector. Economists such as Kaldon, Pasinetti, Kalecki, Domar, Solow, Rommer, Schumpeter and many more, make great contributions that helps to defining how the participation of the Government in the Economy should be. From the Latin American perspective there are also the contributions of the structuralistCepal economists such as Raúl Prebsich, Celso
Monteiro Furtado, etc. For authors such as León Díaz [1] and Enríquez [2], the collaborations of various economists of the time are debated between dynamic equilibrium, uncertainty and production, focusing the discussion on defining, of what magnitude should be the intervention of the State and particularly the government in the Economy.

As for the issue of economic growth, the fundamental variable to measure this is, as already mentioned, GDP, and in particular GDP per capita; "It is proposed that economic growth is the increase in income and the value of the final goods and services produced in the economic system -be it regional, national or international- during a certain period of time-, normally one year, and it is measured through the growth rate of the Gross Domestic Product"[2]. However, when talking about welfare, the situation is complicated, since this concept, by itself, has a multidimensional nature, considering subjective aspects that are difficult to quantify or measure and, above all; which are not necessarily associated with monetary aspects. The main limitation when using GDP as a measure of welfare is trying to equate the latter with measurable factors only in monetary terms [3].

For Nolte [4], the fall in GDP indicates that there has been a decrease in investment and therefore employment, that is, higher unemployment, which leads to less income and therefore greater poverty: less money to buy food, clothing, housing, recreation, health, etc., which ends in a decrease in the levels of welfare and human development. In this same situation, Govea [5] affirms that GDP is an instrument to measure market-oriented activities, but not as an indicator of welfare. According to Bancaja and Ivie [3], GDP... "it does not count the contribution of some productive activities essential for welfare, such as domestic work or caring for children and the elderly at home... it does not count the value of the stock of assets of an economy, ignoring the cost of consumption or the degradation of natural resources" [3:3]

\subsection{Human development}

The contributions of Amartya Sen, -a Hindu economist and philosopher, who received the Nobel Prize in Economics in 1998 for his 
Volume 9 Issue 2 February 2021

contributions to the research of economic welfare, where freedom is fundamental[6] political, economic, social freedom, of transparency and of networks of security-, have contributed greatly to the current concept of human development. The basis for this change in focus was the concept of human development, defined as a process aimed at increasing opportunities for men and women, allowing them to stimulate their potential to the maximum, according to their preferences, needs or interests [4]. Under this vision, the expansion of opportunities is the main means of development [7].

Considering this approach, it is recognized that there is not automatic and direct link between the increase in the average income of a society and human development, so it is necessary to analyze it from a more holistic perspective, in which "true development is to offer all people the maximum opportunities in this direction"[7:29]. It is in this sense that authors such as Amartya Sen [6] affirm that development demands to break down the barriers that prevent individuals from achieving their freedom, such as: poverty, the tyranny of governments, scarce economic opportunities and systematic social deprivation, lack of public services, intolerance and the performance of repressive states, among other aspects.

Based on Sen's approaches, since the 90s, the United Nations (UN) through the United Nations Development Program (UNDP) designed the Human Development Index (HDI), establishing three components to measure development: Longevity, in which life expectancy (life expectancy at birth) is measured, education; that reflects access to knowledge which is necessary to lead a productive life in the new social order: knowing how to read and write is essential for the acquisition of knowledge (average years of schooling and expected years of schooling) and finally, the third component of the Human Development index, this has to do with income levels; decent housing, a well-paid job and social benefits, which is measured by gross national income per capita.

These variables are transformed into indicators and aggregated among themselves through an arithmetic mean obtaining the Human Development Index, which takes values ranging from zero to one [3]. With regard to health, it should be mentioned that, although this has developed significantly in recent decades, the current global pandemic (COVID-19) has exposed the enormous deficiencies that exist around the world on this issue, particularly, the little attention that governments have paid to it, leaving it at the mercy of the free market, which has caused that only a few can access it, generated even more poverty, marginalization and exclusion of all those who cannot pay for medical care (the poor are not market subjects). In this sense, the current crisis shows the urgent need for investment by governments in universal public health.

\subsection{Inequality}

Economic and social inequality is a phenomenon derived from the poor distribution of income and wealth that a society generates, for this reason the Human Development Report [8] presented by the UNDP indicates that when talking about inequality we must refer to the income and wealth of a country. However, inequality occurs, not only in economic aspects but in various facets of human life: health, education, housing, public services, freedom, human dignity, among others.

The most widely used indicator to measure income distribution is the Gini Coefficient or Gini Index, which shows the degree of concentration of income, takes values between zero and one (or one hundred), the closer to zero the greater it will be the distribution of income, that is, less inequality in the distribution of income. The closer a country approaches one hundred, the greater its degree of inequality [8]. Another very common index is the one that uses in its measurement the share of national income that is received by the poorest population, the intermediate one, and the share of national income that is received by the $20 \%$ of the richest population. In this index, Piketty [10] divides society into three groups: the popular class defined as the lowest $50 \%$, the middle class, the middle $40 \%$, and the upper class, which is $10 \%$. higher. Countries such as Norway, Sweden, Germany, among others, are some of the nations with the lowest level of inequality in the world, the countries of Africa and Latin America have the highest levels, with a Gini coefficient higher than 0.5 [11]. 
Volume 9 Issue 2 February 2021

\section{DISCUSSION}

Traditionally, economic growth was understood as synonymous with economic development, in such a way that governments focused their public policies only on encouraging those variables that alluded to growth, such as production, forgetting aspects that have little or nothing to do with the welfare of the population, as is the identity of the peoples, their culture, their traditions, the capacities, abilities and talents of individuals, their human and institutional rights, human dignity, freedom, creed, sustainability, etc. It was not until the 1990s that the vision of development began to have a more comprehensive approach, in which social, institutional, political, economic, cultural, etc. aspects were already considered. This is how the contributions of philosophers and economists such as Sen, Nussbaum, among others, lay the foundations for designing a multidimensional human development approach.

However, it is not enough to recognize that economic growth alone does not generate welfare and of the importance of a holistic vision of human development, it is necessary to identify the factors that prevent countries from raising their levels of development. Unfortunately, we observe a very heterogeneous behavior in the evolution of these variables in different countries, some show a positive relationship between their production growth rates and the human development index, as well as in the decrease in inequality levels, such is the case of the Scandinavian countries and the Netherlands. Others, like the United States, have a very acceptable human development, but very high levels of inequality.

Stiglitz [11], affirms that the inequality that exists in most of the world, is the result of the distortions and inefficiency generated by free market economies, since these, by themselves, exclude all those lacking individuals of economic income. For him, the only Entity capable of reversing this inefficiency is the State, particularly governments with public policy instruments and specifically with an Expansive Fiscal Policy. Authors such as Jiménez [12] agree with Stigliz, pointing out that with higher public spending on education and health, human capacities and skills are enhanced, facilitating future insertion in the job market and therefore higher income in the population. In the same situation we find Burgos and Belén [13] for whom the distribution of income is the key element for individuals to achieve higher levels of welfare. For their part, Bancaja a Ivie [3] also acknowledge that, although GDP per capita is an indicator of economic development, it is inefficient when comparing countries, especially when it comes to nations with low human development, where characteristics and levels of welfare are very heterogeneous. “... when measuring average per capita income, it does not report on the degree of inequality in income distribution" [3:3].

Recognizing that without growth of the Gross Domestic Product, the government does not have income to collect, and therefore money to distribute, it will be necessary to ensure that the resource that it intends to exercise is in the channels and mechanisms that truly impact human development. It is not that governments should not care about economic growth, but rather that they prioritize the need that "...this growth should be evaluated based on whether or not it enables people to perform better and better" [14:1]. Economic growth is a means to achieve the end that is human development and the welfare of the peoples, the problem is that many governments lose themselves in the means and forget the goals or confuse means with goals. It is true that human development, from the perspective of economic theory, is associated with progress, with economic growth and with wealth, which are measured with the Gross Domestic Product [1], but it must be distributed so that they rise levels of human development.

The UN indicates, through the United Nations Development Program [8], that inequality in the field of human development is alarming and heterogeneous, finding countries where GDP growth is relatively high and levels of inequality are also very high, such as the United States, even worse when we talk about indicators of welfare, as is the case of health and education services, which can only be accessed by people who are on the cusp of high incomes, since they are services provided mainly by the private sector, which leaves most of the population of that country out of the market. High inequality can have adverse consequences for social cohesion and the quality of institutions and policies, which in turn can slow down progress in human development [4]. 
Volume 9 Issue 2 February 2021

In a study carried out by Esquivel, López y Velez [16], in which they quantitatively analyze the relationship between the HDI and GDP, it was found that these two variables have a positive correlation, in such a way that regions with higher levels of GDP per capita tend to accumulate physical capital and human development faster and grow faster through an endogenous process [17]. Then, the reflection that jumps out is the following, if we recognize that GDP is only a monetary variable, which is not a synonym or indicator of welfare, but that, nevertheless, is required to finance the expenses that human development implies: more schools, hospitals, roads, etc. The following question arises: What is required for GDP growth to translate into greater welfare and human development? For the increases in the Gross Domestic Product of a country to be reflected in higher levels of welfare of the population, it is required that this (GDP) be distributed among the population through tax collection first and then with the public services that the government provides. So, does GDP growth and the decrease in inequality have some kind of relationship? Not necessarily, if there are not adequate income distribution mechanisms in a country, these variables will be completely unrelated.

The variables that do maintain a close relationship are human development and inequality, since the former implies greater social spending by the government; education, health, housing, per capita income, etc., and to achieve these, the government must spend more of their income, which they obtain (to a large extent) from taxes: it takes away those who have more to give to those who have little, redistributes income.

\section{MATERIALS, METHODS AND RESULTS}

This is a mixed research of exploratory, descriptive correlational scope, in which the relationship between the variable's inequality, human development and economic growth is shown, measured through the Gini Coefficient, the Human Development Index and the real Gross Domestic Product, respectively. The central hypothesis is that, -although inequality and human development require GDP growth to be financed-, economic growth does not automatically generate a higher human development index, much less does it translate into lower levels of social inequality. The analysis of the relationship between HDI and real GDP was synchronous: a single year, 2018. While the relationship between HDI and inequality was diachronic, it was necessary to observe its behavior over time (1990-2018).

\subsection{Linear Regression between HDI and real GDP}

With data from the Human Development Index published by the United Nations [15,18] and with mega data from the World Bank [19], a group of 20 countries with the highest human development for 2018 was chosen, which are ranked in the following order: Norway, Switzerland, Ireland, Germany, Hong Kong, Australia, Iceland, Sweden, Singapore, Netherlands, Denmark, Finland, Canada, New Zealand, United States, Belgium, Liechtenstein, Japan and Austria, with their respective real GDP for that same year [20].

From the study carried out by Ortiz, Hernandez and Martínez [21] the dispersion graphs for both groups of countries were obtained.

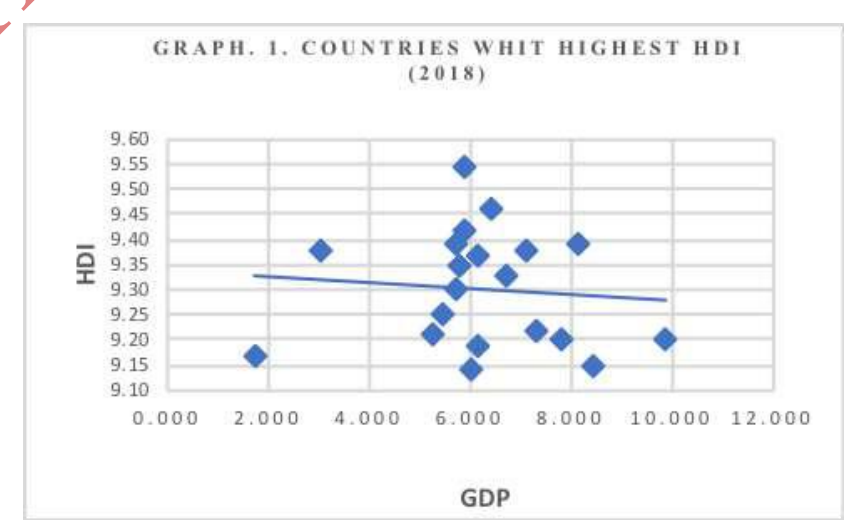

In the graph we can see the poor relationship between HDI and GDP. In addition, due to their slope, we can affirm that they maintain a negative relationship [21].

Another group, also of 20, with the lowest development, starting with the one with the lowest HDI in the world and are the following: Niger, Central African Republic, Chad, South Sudan, Burundi, Mali, Eritrea, Burkina Faso, Sierra Leone, Mozambique, Democratic Republic of the Congo, Bissau Guinea, Yemen, Liberia, Guinea, Gambia, Ethiopia, Malawi, Malawi, Djibouti and 
Volume 9 Issue 2 February 2021

Afghanistan. Likewise, with their respective HDI and real GDP for 2018.

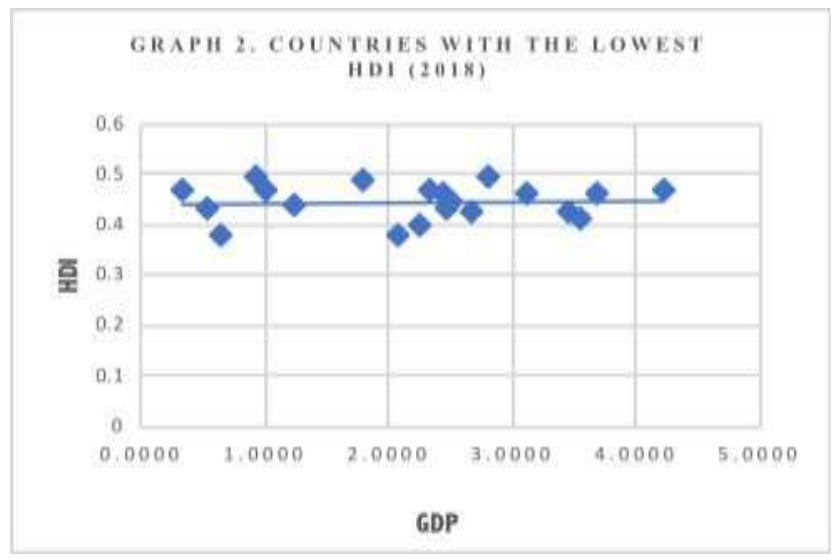

In this graph, like the previous one, the relationship between the two variables is almost nil, however, in this case, such relationship is positive: HDI and GDP move in the same direction.

Based on the data from each country, the relationship between the HDI and GDP was quantified through simple linear regression por Ortiz, Hernández and Martínez [21]. Which, according to Schimidt [22] indicates whether two variables maintain a relationship and the degree of dependence between them, the estimated mathematical equation was posed as follows:

$$
\mathrm{HDI}=\beta_{0}+\beta_{1} \mathrm{GDP}_{\text {real }}+\varepsilon
$$

The results obtained gave us an $r$ close to $0,(r \rightarrow 0)$ and the mathematical equations for each group are shown below:

For Developed countries:

$$
\mathrm{HDI}_{(\text {des. })}=0.932-7.167 \times 10^{(-11)} \mathrm{GDP}_{\text {real }}+
$$

For Non-developing countries:

$$
\begin{aligned}
\mathrm{HDI}_{(\text {not des })}= & 0.442+1.963 \times 10^{(-8)} \mathrm{GDP} \\
\text { real } & +\varepsilon^{\wedge}
\end{aligned}
$$

The mathematical equations obtained lead us to affirm that changes in production do not have an impact on the Human Development Index [21] or that such impact is negligible. From what we can affirm that there is no relationship between these two variables. However, it should be noted that the negligible relationship is positive in the case of less developed countries.

\subsection{Linear Regression between Gini Coefficient and HDI}

For the analysis of the relationship between human development and inequality, the HDI and the Gini Coefficient for two years were considered; 1990 and 2018 [20], from a group of countries with different levels of economic development and are the following: Germany, Switzerland, Denmark, Belgium, Canada, United States, Netherlands, Norway, Sweden, Finland, Mexico, Brazil, Chile, Colombia, Paraguay, Argentina, Uruguay, Egypt, India and China.

The research carried out by Ortiz, Hernández and Martínez [23] shows us a scatter plot for each year and they are as follows.

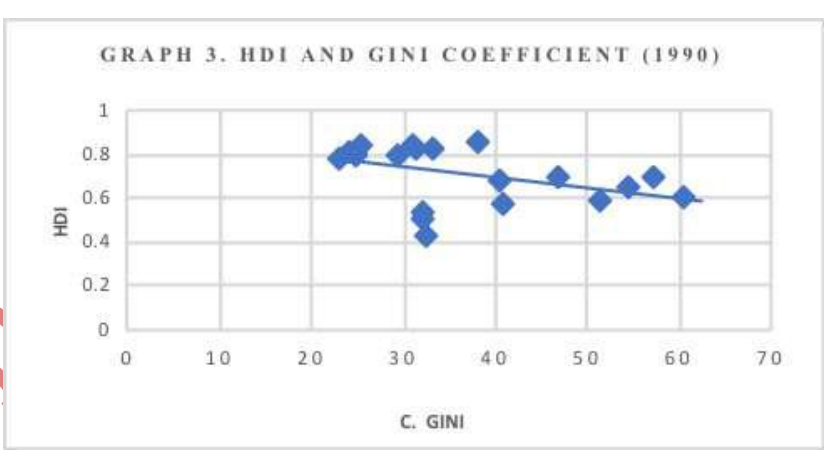

Almost 30 years later, the graph is as follows:

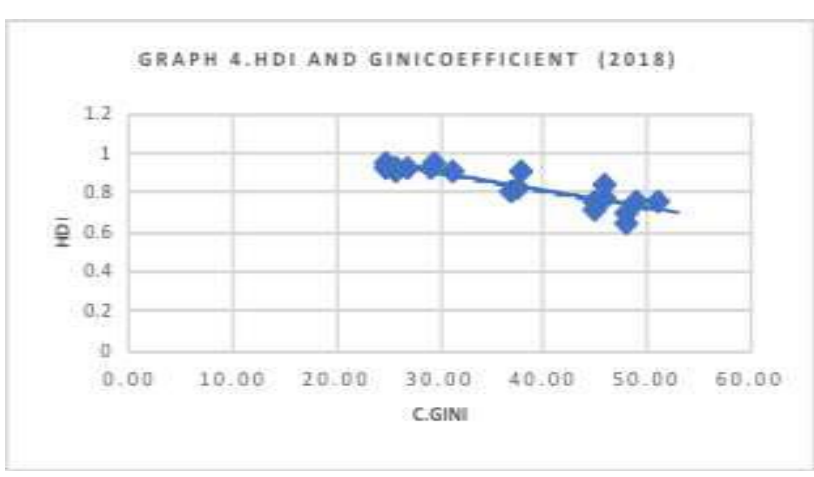

The dispersion graphs between HDI and Gini coefficient show a significant relationship between both variables. Which is inverse, if one increases the other decreases.

After obtaining the data, the simple linear relationship between the Index and the Coefficient was calculated, for each of the two years, the equation to be estimated was [23]:

$$
\text { HDI }=\beta_{0}+\beta_{1} \text { C. Gini }+\varepsilon
$$


Volume 9 Issue 2 February 2021

Which shows to what extent human development (HDI) is determined by income distribution (C. Gini). For both cases, a positive result was obtained in $r$, being higher in $2018(r=803)$. The mathematical equations obtained from the simple linear regression for each of the two years were the following:

For the year 1990:

$$
\mathrm{HDI}_{1990}=0.876-.004 \mathrm{C} \cdot \mathrm{Gini}+\varepsilon^{\wedge}
$$

For the year 2018:

$$
\mathrm{HDI}_{2018}=1.177-.009 \mathrm{C} \cdot \mathrm{Gini}+\varepsilon^{\wedge}
$$

According to both equations, a decrease in the Gini value (greater distribution of income) brings with it an increase in the Human Development Index and, on the contrary, a lower distribution of income reduces human development. Therefore, to raise the HDI, governments must not only put the accent on encouraging economic growth. They must also implement a series of public policy mechanisms to distribute production (income).

\section{CONCLUSIONS}

Recognizing that GDP is an indicator that shows the degree of growth of investment, employment and therefore of national income, part of which goes to the hands of the government, which is the designer and implementer of public policies aimed at providing health, housing, public security, etc., therefore; growth if necessary to achieve increased human development. But, despite knowing that GDP is the fundamental variable when it comes to talking about economic growth, it is not when we talk about welfare and inequality. Nations with high economic growth do not necessarily have greater welfare: better education, better health services, better income, etc. Not much less does it tell us in whose hands the income derived from increased production is. In this way, the results obtained clearly show three fundamental aspects:

1) Economic growth is important, since the increase in GDP brings with it more investment, more jobs, more income and therefore higher tax collection (increase in budget income), which is necessary to finance public spending policy.

2) However, even if there is economic growth and government revenues increase, there is not guarantee that these will later translate into higher public spending. Therefore, the relationship between Economic Growth (GDP) and Human Development (HDI) is not automatic. Production can grow and deficiencies in health, education, housing, income, etc., be increased.

3) So, for economic growth to translate into welfare, there must also be an efficient distribution of wealth. That is, reduce inequality.

Thus, it is clear that the government has a preponderant place when it comes to talking about human development and social inequality, since it is the active agent of change, it is up to him to create the legal-institutional and economic mechanisms that enable efficient distribution and equitable income, which can be done through a redistributive fiscal policy coupled with a social spending policy.

\section{REFERENCES}

[1]. Leon Diaz J. (2007). Keynesianism, PostKeynesianism and Newkeynesianism: ¿Three different doctrines just one real theory?, Munich Personal RePEc Archive, Universidad Nacional de Colombia, Colombia en: Online at https://mpra.ub.unimuenchen.de/4600/ MPRA Paper No. 4600, posted 29 Aug 2007

[2]. Enriquez Pérez, Isaac (2016). Las teorías del crecimiemto económico: notas criticas para incursionar en un debate inconcluso. Revista Latinoamericana de Desarrollo Económico, ISSN 2074-4706 SCIELO.," J. Name Stand. Abbrev., in press.

[3]. Bancaja e Ivie (2010). CAPITAL HUMANO, DESARROLLO HUMANO, compromiso social. Fundación Bancaja e Ivie, cuaderno 114, España

[4]. Nolte Manfred (2014). PIB Desarrollo Humano y Bienestar. Derechos Humanos, Economía, Pobreza. Available in: https://blog.cristianismeijusticia.net/2014/09/1 9/pib-desarrollo-humano-y-bienestar

[5]. Govea Maridueña, A. (2018). Evolución e impacto del PIB y el IDH en un mundo desigual. Available in review Vinculando: http://vinculando.org/sociedadc ivil/evolucion-e-impacto-pib-idh-mundodesigual.html 
Volume 9 Issue 2 February 2021

[6]. Sen Amartya (2000). "El desarrollo como libertad”. Gaceta Ecológica, ISSN: 1405-2849, , núm., 55, pp 14.20. Secretaria de Medio Ambiente y Recursos Naturales, Distrito Federal, México, Available in: https://www.redalyc.org/articulo.oa?id=53905 501

[7]. Informe de Desarrollo Humano Municipal 2010-2015 (2019). Transformando a México desde lo local. México: PNUD-México.

[8]. Informe sobre el Desarrollo Humano (2019). Panorama General, Mas allá del ingreso, más allá de los promedios, más alá del presente: Desigualdades de desarrollo humano en el siglo XXI. Programa de las Naciones Unidas para el Desarrollo, ONU, Estados Unidos.

[9]. Lizárraga Mollinero C. (2013). EL INDICE DE GINI: La desigualdad a la palestra. Extoikos, ISSN-e 2173-2035, No.10

[10]. Bustos Serrano F.J. (2018). La desigualdad según Piketty. Disponible en: http://www.elcaptor.com/economia/ladesigualdad-según piketty\#: :text=En\%20su\%20libro\%20\%E2\% 80\%9CE1\%20capital,econ\%C3\%B3mica\%20e n\%20nuestra\%20sociedad\%20actual.\&text=La $\% 20$ primera $\% 20$ conclusi\%C3\%B3n\%20a\%20 la,que $\% 20$ en $\% 20$ cuanto $\% 20$ al $\% 20 \mathrm{tr}$

[11]. Stiglitz Joseph. E (2012). EL PRECIO DE LA DESIGUALDAD, el $1 \%$ de la población tiene lo que el $99 \%$ necesita. Ebook, Editorial Taurus.

[12]. Jiménez, Juan P. (2015). Desigualdad, concentración del ingreso y tributación sobre las altas rentas en América Latina, Centro de estudios fiscales, CEPAL, Santiago Chile.

[13]. Burgos, Miguel y Belén Ana (2015). La medición del bienestar económico a través de las macro magnitudes de la Contabilidad Nacional, CIRIEC-España, Revista de Economía Pública, Social y Cooperativa, núm. 85, ISSN: 0213-8093

[14]. Freddy Edison y Fernández Tene (2018) El desarrollo humano y social. Available in: https://www.researchgate.net/publication/3281
26666_El_desarrollo_humano_y_social, consultado el 15 de junio 2020.

[15]. Índice e indicadores de desarrollo humano (2018). Índice e indicadores de desarrollo humano, actualización estadística 2018. Estados Unidos: Programa de las Naciones Unidas para el desarrollo, ONU.

[16]. Esquivel Hernández G., López Calva, L.F. y Vélez, G. R. (2003). Crecimiento económico, desarrollo humano y desigualdad regional en México 1950-2000. México: Estudio sobre Desarrollo Humano, PNUD

[17]. Angeles-Castro Gerardo (2013). Crecimiento económico y desarrollo humano en la ciudad de México con respecto a un entorno nacional: una perspectiva neoclasica y dualista. Economía y Territorio, Vol. 13, No. 42, Toluca México, Available in: http://www.scielo.org.mx/scielo.php?script=sci _arttext\&pid=S1405-84212013000200006.

https://economipedia.com/ranking/ranking-

indice-de-desarrollo-humano-2018.html

[18]. https://databank.bancomundial.org/home.a spx

[19]. https://datos.bancomundial.org/indicator/S I.POV.GINI

[20]. Ortiz Medina I. Hernández Ortiz M y Martínez Pérez J. (2020). Producto Interno Bruto e Índice de Desarrollo Humano: Dos variables inconexas, Revista de Ciencias Sociales Vol. 29 Núm. 44. Primer Semestre 2020 (Ene-Jun) ISSN 0717-2257 - ISSN 07183631

[21]. Schimidt J. (2005). Econometria. México DF: McGraw-Hill, Interamericana

[22]. Ortiz Medina I. Hernández Ortiz M y Martínez Pérez J. (2020). Desarrollo humano y desigualdad: análisis de la distribución del ingreso, European Public and Social Innovation Review, Volumen 5, ISSEU 2, ISSN: 2529-9824 